\title{
Tropical ant communities are in long-term equilibrium
}

\author{
David A. Donoso \\ Instituto de Ciencias Biológicas, Escuela Politécnica Nacional, Av. Ladrón de Guevara E11-253, Quito, Ecuador
}

\section{A R T I C L E I N F O}

\section{Article history:}

Received 13 June 2016

Received in revised form 10 March 2017

Accepted 13 March 2017

Available online 23 March 2017

\section{Keywords:}

Andes cloud forests

Monitoring

Otongachi

Rank abundance

Temporal turnover

Leaf litter ants

\begin{abstract}
A B S T R A C T
Communities change with time. Studying long-term change in community structure permits deeper understanding of community dynamics, and allows us to forecast community responses to perturbations at local (e.g. fire, secondary succession) and global (e.g. desertification, global warming) spatial scales. Monitoring efforts exploring the temporal dynamics of indicator taxa are therefore a critical part of conservation agendas. Here, the temporal dynamics of the Otongachi leaf litter ant community, occurring in a cloud forest in coastal Ecuador, were explored. By sampling this community six times over eleven years, I assessed how the ant fauna caught by Winkler traps (more diverse and cryptic fauna) and caught by pitfall traps (larger, more mobile fauna) changed over time. The Otongachi leaf litter ant community was dynamic. Although species richness in the community remained constant, temporal turnover of species was high: on average, 51\% of the ant species in Winkler traps, and 56\% of those in pitfall traps, were replaced with other ant species from one year to the other. Shifts in the rank abundance of species in the community were also large across the eleven years and, on average, shifts in the rank abundance of species collected by Winkler traps doubled those occurring in pitfall traps from one census to the other. In spite of these trends, the Otongachi ant fauna showed no (Winkler) or weak (pitfall) evidence of directional change (towards a new community). Thus, this tropical ant community can be divided in two community compartments. The Winkler compartment composed by a more diverse and cryptic ant fauna appears to be resilient and stable in time. The pitfall compartment composed by larger and more mobile ants may be prone to respond to disturbance. This study suggests that 1) species appearing/disappearing from a site may be rather the rule, difficult to separate from responses to ecological stress. 2) Conclusions made in short-term studies, or studies comparing two (e.g. before and after) snapshots of a community, should thus be revisited. Finally, 3 ) the ant fauna caught by pitfall traps (a rather simple and cheap survey method) is the most likely community compartment to indicate ecological perturbation. This study adds to the growing evidence that using ants as ecological indicators should incorporate long-term temporal dynamics.
\end{abstract}

(C) 2017 Elsevier Ltd. All rights reserved.

\section{Introduction}

Natural communities change over time (Butchart et al., 2010; Magurran et al., 2010). Studying temporal community dynamics is of interest because the relative importance of different processes structuring ecological communities changes with time (Matthews et al., 2013; Baez et al., 2016). Examining long-term community dynamics also allow us to test how ecological stressors (e.g. anthropogenic disturbance, global warming, invasive species, El Niño Southern Oscillation) impact communities (Magurran et al., 2010; Colwell et al., 2008). As such, these dynamics can provide helpful insights to improve conservation efforts (Butchart et al., 2010). Unfortunately, temporal changes of naturally occurring commu-

E-mail address: david.donosov@gmail.com nities are difficult to measure. It requires long-term funding and institutional support, as well as expertise in taxonomy (Bonada et al., 2006; Majer et al., 2007; Lenoir and Svenning 2013). As a consequence, our knowledge of the temporal dynamics that communities experience under natural conditions is limited. This is especially true for insect communities in tropical environments, and refrain us from using insect taxa as effective ecological indicators (Agosti et al., 2000).

Despite difficulties, interest in long-term community dynamics has grown with time, and long-term ecological research is now well incorporated into mainstream ecological research agendas (e.g. Long Term Ecological Research Network, Callahan 1984; National Ecological Observatory Network, Kampe et al., 2010; CTFS-Forest GEO Network, Anderson-Teixeira et al., 2015). New conceptual frameworks exploring how communities change over time measure trajectories of multiple species simultaneously in a 
multivariate space (Magurran et al., 2010). These temporal analyses emphasize the role of direction and gradualism of community trajectories (Collins et al., 2000; Matthews et al., 2013). Communities are considered to be stable if changes in community structure do not accumulate with time. Alternatively, communities show direction if changes in community structure accumulate with time and either diverge from, or converge towards, an original state, which is usually assumed to be the reference community sampled first (Collins et al., 2000; Matthews et al., 2013). Another important aspect of temporal dynamics is the rate of change in community structure (Collins, 2000). Gradual changes are considered the norm, and occur when communities experience minor and constant changes from one year to the other. Contrary to gradual change, saltatory change is expected to occur when communities experience rapid major disturbances (Collins, 2000). Generally, the ability of a community to return gradually to its original state is considered as positive, especially within conservation or restoration agendas (Majer et al., 2013). Communities are said to be in equilibrium if, despite year-to-year variability, community structure remains constant (Collins, 2000).

Ants are conspicuous organisms in soil ecosystems, and participate in a myriad of ecological interactions (Del Toro et al., 2012; Tiede et al., 2017). Several authors have proposed ants as good ecological indicators (Andersen 1990; Arcila and Lozano-Zambrano, 2003) and methods exist to monitor ants (Agosti et al., 2000). However, most studies examining ant communities through time compare two points; and thus they do not constitute 'temporal' studies in a strict sense (defined here as communities surveyed three or more times). These studies tend to compare disturbed plots (after a certain time) with nearby control treatments (Table 1 ). For example, recently, Belcher et al. (2016) resampled M.R. Smithís 1926 survey of invasive ants in Urbana (Illinois, USA) after 87 years. Whereas they found that the four most common house ants differed between the two sampling times, the similarity of the complete faunas was unanticipated. In a different approach, some studies have used chronosequences, i.e. a space-for-time substitution (Hoffman and Andersen, 2003; Majer et al., 2007) to monitor temporal change (Table 1). In Australia, for example, ants have been used to monitor restoration of mining sites (Majer et al., 1982; Majer, 1983; Hoffman and Andersen, 2003) and ecosystem responses to fire (Andersen 1991). Evidence thus far suggests that ant communities can show directional (Gosper et al., 2012) and stable trajectories (da Conceição et al., 2015). In Brazil (Bihn et al., 2010) and Puerto Rico (Barberena-Arias and Aide 2003), ants have been used to monitor secondary succession. These studies show directional and saltatory trajectories with little or no sign of communities returning to the original state (Barberena-Arias and Aide 2003, Bihn et al., 2010). However, in Costa Rica, Patrick et al. (2012) found that, after 12 years, treefall gaps had little or no effect on the structure of ant communities living in those gaps. While the number of published studies is likely too small to suggest strong patterns (Table 1 ), the majority of these studies show that ant communities are certainly responding to disturbance, but see Tiede et al. (2017).

To the best of my knowledge, no temporal survey of naturally occurring ant communities has been documented to date. Here I surveyed the leaf litter ant fauna of the Otongachi forest six times $(2003,2006,2008,2009,2011$, and 2013) over eleven years. I aimed to understand the changes in structure that a tropical leaf litter ant community experiences naturally over a decade. Using what is the longest dataset available for any ant community, I ask 1) are temporal changes occurring in a gradual or saltatory way? 2) Is there evidence of changes in the general abundance of species with time? And 3 ) is there evidence of directional or stable trajectories in this ant community with time? I answered these questions by looking at the responses of two compartments of the leaf litter ant community. Previously, Donoso and Ramoín (2009) have shown that pitfall and Winkler traps capture different subsets of the ant community. In the Otongachi forest, the ant fauna caught by Winkler traps was more diverse and cryptic than the larger and long-legged (more mobile) ant species captured by pitfall traps (Donoso and Ramoín, 2009).

\section{Materials and methods}

\subsection{Study area}

This study was conducted within the Otongachi forest $\left(00^{\circ}\right.$

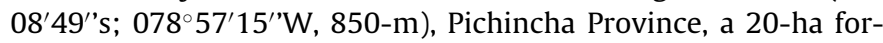
est patch in the lowest-most part of the Bosque Integral Otonga (BIO Reserve). The forest is located on the western slopes of the Ecuadorian Andes, near La-Unión-del-Toachi town. Otongachi is a secondary wet pre-montane forest (Cañadas (1983)) that was modified until the year 2000 by low-intensity selective timber harvesting [timber of Cedrela odorata L. (Cedro), Nectandra sp. (Canelo), and Guadua sp. (Caña guadua) was logged down from the site; G. Onore, personal communication]. The average annual temperature is $18-24^{\circ} \mathrm{C}$, and the annual rainfall is between 1000 and $2000 \mathrm{~mm}$. Forest leaf litter was composed of plant species from sub-tropical, cloud and Andean forests, including Cedrela odorata L. "cedro", Billia columbiana Planch. and Linden "pacche", Elaegia utilis (Goudot) "lacre", Guarea kunthiana A. Juss "colorado", Pochota squamigera (Cuatrec.) "frutipan”, Sapium verum Hemsl. "lechero" and Nectandra acutifolia (Ruiz and Pav) “Gigua” (Jaramillo, 2001).

\subsection{Ant sampling}

The Otongachi forest was surveyed in six censuses spanning eleven years. In years 2003, 2006, 2008, 2009, 2011, and 2013, ant communities were sampled using the Ants of the Leaf Litter (ALL) protocol as described in Agosti et al. (2000). In each year, ant assemblages were sampled using a complete replicate of the ALL protocol, in August-September, during a period of low rain. Each transect consisted of 20 sampling points separated by $10 \mathrm{~m}$ for a total extent of $200 \mathrm{~m}$. Because litter removal is destructive and may influence ant community structure (Donoso et al., 2013), the starting sampling point and direction of the transect was chosen every year in a haphazardly way, always starting near the research station. At each sampling point, a randomly placed pitfall trap partially filled with $70 \%$ alcohol for $48 \mathrm{~h}$ was used alongside leaf litter from a nearby $1-\mathrm{m}^{2}$ plot that was placed in a Winkler extractor. The 2003 census, measuring ant community structure at the Otongachi forest, was reported by Donoso and Ramoín (2009). Further sampling methodology details are available there.

Samples were processed in the laboratory. From every sample, at least one individual of each morphospecies was mounted and labeled, and the abundance of the morphospecies was recorded. Specimens were identified to species with the use of taxonomic keys and local reference collections. Where specific identifications were not possible, specimens were assigned to a morphospecies. I compared specimens with those deposited at the Ecuadorian Ant Reference Collection (ARCE), housed in the EPN Museum (Museo de Historia Natural Gustavo Orcés V.) at the Instituto de Ciencias Biológicas of the Escuela Politécnica Nacional (Quito, Ecuador), and curated by DAD. Ants identified to morphospecies bear an ARCE morphospecies number (EC\#\#\#). ARCE serves as a national reference collection for ant species of Ecuador. Additional voucher specimens of all species and morphospecies have been deposited in the MUTPL Museum at the Universidad Técnica Particular de Loja (Loja, Ecuador). 
Table 1

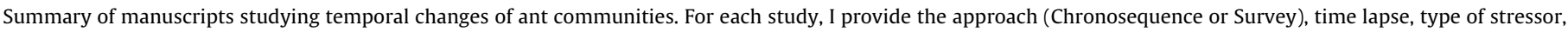
and type of response [Directional (D) vs. Non Directional (ND), Saltatory (S) vs. Gradual (G), Return (R) vs. No Return (NR)].

\begin{tabular}{|c|c|c|c|c|c|c|}
\hline Study & Type & Extent $(\mathrm{yr})$ & Frecuency Survey & Stressor & Type of response & Note \\
\hline Gosper et al., 2012 & Chronosequence & 300 & $<12,38-120,>140$ & Fire & $\mathrm{D}, \mathrm{G}, \mathrm{R}$ & Interpreted \\
\hline Jackson and Fox 1996 & Chronosequence & 18 & $1,6,12,18$ & Fire & $\mathrm{ND}, \mathrm{G}, \mathrm{R}$ & Interpreted \\
\hline Jackson and Fox 1996 & Chronosequence & 18 & $1,6,12,18$ & Mine & $\mathrm{ND}, \mathrm{S}, \mathrm{NR}$ & Interpreted \\
\hline Majer et al., 1984 & Chronosequence & 13 & various & Mine & $D, G, N R$ & Interpreted \\
\hline Patrick et al., 2012 & Chronosequence & 12 & $1-12$, yearly & Gap & $\mathrm{ND}, \mathrm{G}, \mathrm{NR}$ & Interpreted \\
\hline Jackson and Fox 1996 & Chronosequence & 18 & $1,6,12,18$ & Clearing & $\mathrm{ND}, \mathrm{S}, \mathrm{NR}$ & Interpreted \\
\hline da Conceição et al., 2015 & Chronosequence & 33 & $1,3,4,8,15,33$ & Agriculture & Unknown & Interpreted \\
\hline Lafleur et al., 2006 & Chronosequence & 79 & $1,9,23,47,79$ & Fire & $\mathrm{ND}, \mathrm{S}, \mathrm{R}$ & Reanalysed \\
\hline Barberena-Arias \& Aide 2003 & Chronosequence & 60 & $5,30,60$ & Secondary Succesion & $\mathrm{D}, \mathrm{S}, \mathrm{NR}$ & Interpreted \\
\hline Bihn et al., 2010 & Chronosequence & 60 & $4-6,10-15,35-50,>100$ & Secondary Succesion & $\mathrm{D}, \mathrm{S}, \mathrm{NR}$ & Interpreted \\
\hline Vanderwoude et al., 2000 & Chronosequence & 40 & $1-5,6-10,11-20,21-30,>30$ & Timber harvesting & $\mathrm{D}, \mathrm{S}, \mathrm{R}$ & Interpreted \\
\hline Majer 1981 & Survey & 2 & monthly & Mine & $\mathrm{ND}, \mathrm{G}, \mathrm{NR}$ & Interpreted \\
\hline Majer and Nichols 1998 & Survey & 14 & $1-14$ yearly & Mine & $\mathrm{D}, \mathrm{G}, \mathrm{NR}$ & Interpreted \\
\hline Belcher et al., 2016 & Survey & 87 & 1,87 & Land Conversion/Housing & ND & Interpreted \\
\hline Donoso, 2017(This study) & Survey & 11 & $0,3,5,6,8,10$ & Secondary Succesion & $\mathrm{ND}, \mathrm{G}, \mathrm{NR}$ & This study \\
\hline
\end{tabular}

Directional (D) vs. Non Directional (ND)

Saltatory (S) vs. Gradual (G)

Return (R) vs. No Return (NR)

\subsection{Statistical analyses}

A dataset consisting of ant species present by trap (Winkler sacs and pitfall traps) and by year (6 censuses) was compiled. Singletons, defined here as species occurring once within the survey, and nomadic ant species, depicting the army ant syndrome (e.g., Ceraphachys, Neivamyrmex, Labidus) were removed from analyses. Removing singletons species lessen the influence of rare species in community analyses. Army ants do not permanently inhabit a patch of litter, and are usually trapped by these methods in large numbers, biasing the true, more permanent composition of the plots. Other species with special biology (such as Atta cephalotes, that build large long-term permanent nests, different to most other leaf-litter ants), and species with taxonomic uncertainties were also removed from analyses. In the Neotropics, species of the ant genus Solenopsis are difficult to sort apart, and thus all specimens/species of this genus were merged into a single category.

Temporal changes in ant diversity of the Otongachi ant community were characterized using three different temporal metrics; these metrics have been recently implemented in the $\mathrm{R}$ library "codyn" (Hallett et al., 2015, 2016). First, I investigated if the rate of change of community structure across the eleven-year interval shows a gradual or saltatory trajectory. For this, total species turnover (tST) in the community was calculated among consecutive censuses. The variable tST measures the proportion of total species richness lost and gained in the community from one year to the next, and ranges from 0 (no species are gained or lost) to 1 (all species are replaced). Communities may differ in species turnover even when total species richness remains constant over time. We can decompose tST further into two indices, such that all species appearing (aST) and disappearing (dST) over time are measured by calculating the proportion of species gained or lost with respect to that of the complete community. Large or unexpected values of ST from one year to the next surveyed year allow us to see if a saltatory (non-gradual or abrupt) change in community structure has occurred.

Second, mean shifts in species rank abundances (MRA; Collins et al., 2008) were calculated. MRA, an overall measure of changes of species abundances within the community, is the sum of species common to two sampling times weighted for the relative rank abundance change that the species displayed. Higher values of MRA indicate a higher amount of reshuffling in species ranks within a community. However, MRA values are a function of the total number of species in a community, as more species provide more room for species reshuffling, and thus MRA should be higher in more speciose communities.

Finally, I measured the rate of directional change in community composition over time (Collins et al., 2000; Matthews et al., 2013). The rate of directional change was calculated from distance measures (here I used Euclidean distance) between time points. When these distances are regressed over time, the slope of the regression indicates the stability of the community over time. A slope of zero indicates that the community remains stable and that no change in structure occurs with time. Positive, linear and significant slopes indicate unstable communities with directional temporal trajectories. Negative, linear and significant slopes indicate unstable communities with convergent temporal trajectories (Collins et al., 2000).

\section{Results}

\subsection{Ant sampling}

The initial dataset coming from six censuses spanning eleven years shows a total of 12342 ant specimens coming from 126 species and 52 genera (Table A1 in Appendix A). Of these, 20 singleton species were removed from further analyses. Sixteen additional species were also removed because they were army ants or taxonomic difficulties. In the final dataset, the five most common species found were Nylanderia EC004 ( $\mathrm{n}=650$ specimens), Pheidole EC009 $(\mathrm{n}=622)$, Cyphomyrmex EC003 $(\mathrm{n}=531)$, Hypoponera distinguenda $(\mathrm{n}=412)$ and Octostruma EC001 $(\mathrm{n}=410)$. But, these species were not always the most abundant as the ranking was highly variable from year to year (Table 2 ). In total six species, which I call here the 'core' species, were in the top-five of species abundances in the 11-year interval. Ten additional species, which I call here the 'occasional' species, reached the top five only once in the 11-year interval (Table 2).

The mean number of species present each year was 58 . The mean number of species present in Winkler traps $(n=50)$ broadly doubled the species in pitfall traps $(n=30)$. On average, in each sampling year I found 5 singletons. Ant species richness in the Otongachi forest remained constant with time (Fig. 1).

\subsection{Changes in species turnover}

The Otongachi ant community presented high levels of species turnover across the years, but the pattern shows mostly gradual 
Table 2

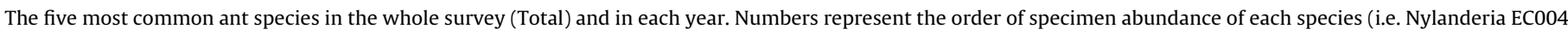

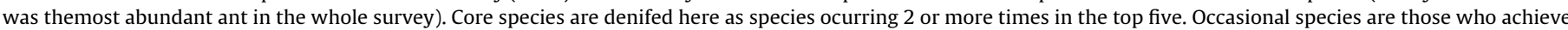
high abundance only in one year.

\begin{tabular}{|c|c|c|c|c|c|c|c|c|}
\hline & Year & Total & 2003 & 2006 & 2008 & 2009 & 2011 & 2013 \\
\hline \multirow[t]{6}{*}{ Core Species } & Nylanderia EC004 & 1 & 2 & & 1 & 2 & 1 & \\
\hline & Pheidole EC009 & 2 & 3 & 1 & & 1 & 3 & \\
\hline & Cyphomyrmex EC003 & 3 & & 3 & 2 & 4 & 2 & 4 \\
\hline & Hypoponera distinguenda & 4 & & 2 & & & & 1 \\
\hline & Octostruma EC001 & 5 & & & & 3 & & 3 \\
\hline & Gnamptogenys bisulca & & 4 & 4 & 3 & & & \\
\hline \multirow[t]{10}{*}{ Occasional Species } & Azteca EC001 & & 1 & & & & & \\
\hline & Pheidole EC001 & & 5 & & & & & \\
\hline & Pheidole EC003 & & & 5 & & & & \\
\hline & Pheidole EC016 & & & & 4 & & & \\
\hline & Pheidole EC002 & & & & 5 & & & \\
\hline & Brachymyrmex EC001 & & & & & 5 & & \\
\hline & Pheidole onyx & & & & & & 4 & \\
\hline & Carebara urichi & & & & & & 5 & \\
\hline & Octostruma EC002 & & & & & & & 2 \\
\hline & Pheidole EC005 & & & & & & & 5 \\
\hline
\end{tabular}

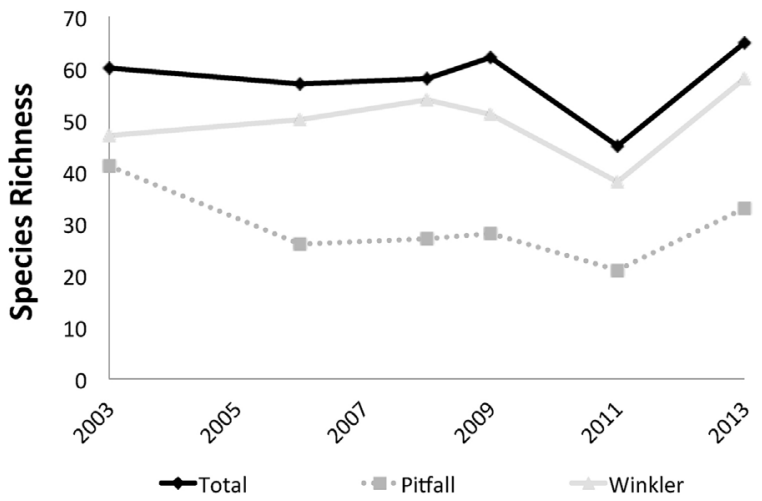

Fig. 1. Ant species richness in the Otongachi forest across eleven years. Total species richness, and species trapped by pitfall and Winkler traps are provided.

change (no abrupt difference in the rate of species turnover from year to the other, Fig. 1). The mean tST in Winkler traps was 0.51 (on average, $51 \%$ of the species sampled by Winkler traps in one year did not showed up in the year after) and mean tST in pitfall traps was 0.56 . Winkler and pitfall traps showed a similar temporal pattern, where species turnover slightly decreased or was kept constant in time, but showed a spike in the last census interval (i.e. 2011-2013; Fig. 2). Species appearances and disappearances contributed equally to the pattern (mean Winkler aST $=0.27$, mean Winkler dST $=0.24$, mean pitfall aST $=0.26$, mean pitfall dST $=0.30$ ).

\subsection{Changes in species abundance}

Shifts in species rank abundances showed differences between Winkler and pitfall traps. On average, rank abundance changes in the ant community collected by Winkler traps doubled (Winkler MRA $=6.63$ ) that of pitfall traps (pitfall MRA=3.29). MRA values for both Winkler and pitfall traps also changed with time (Fig. 3). Winkler MRAs peaked at 2008, but then declined constantly. Pitfall MRAs peaked in 2006, after which it stabilized around a value of 3 (Fig. 3)

\subsection{Changes in directionality}

Across the 11-year census, neither directional change nor convergence was found in Winkler traps. The regression line of community similarity vs. census interval was positive, but it was not significant and explained little variation $(F=0.30, p=0.59$,
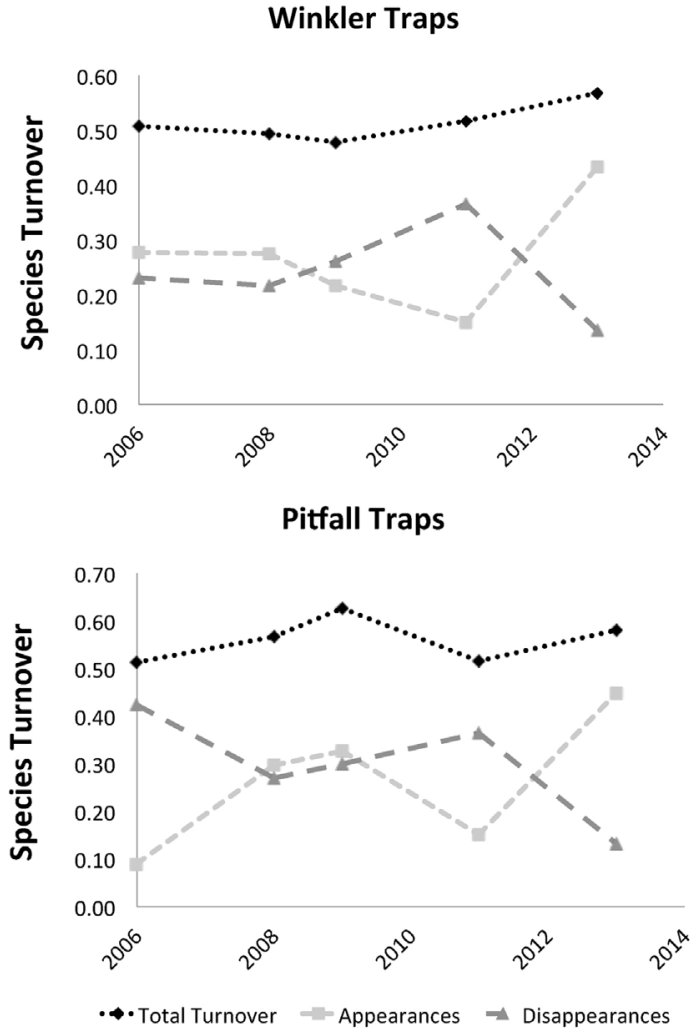

Fig. 2. Species turnover within the Otongachi ant community across eleven years by trap type (Winkler vs. pitfall). Total species turnover (tST) is divided among those ant species appearing (aST), and those ant species disappearing (dST) with time.

$\mathrm{R}^{2}=0.02$, Fig. $4 \mathrm{~A}$ ). However, for pitfall traps, I detected a significant positive change during the study interval $(F=5.41, p=0.036$, $\mathrm{R}^{2}=0.29$, Fig. $\left.4 \mathrm{~B}\right)$.

\section{Discussion}

The Otongachi ant community was highly dynamic from one census to the other. However, over the course of the 11-year study there was not an apparent decrease of species richness either in Winkler traps or pitfall traps. More importantly, there was no longterm change in the community sampled by Winkler traps, and the pitfall community only weakly changed. The remarkably high tem- 


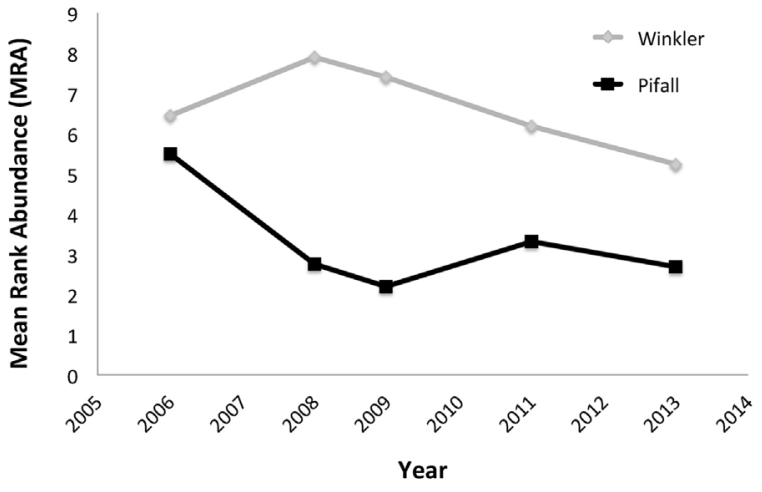

Fig. 3. Mean rank abundance (MRA) changes in the ant community over 11 years.

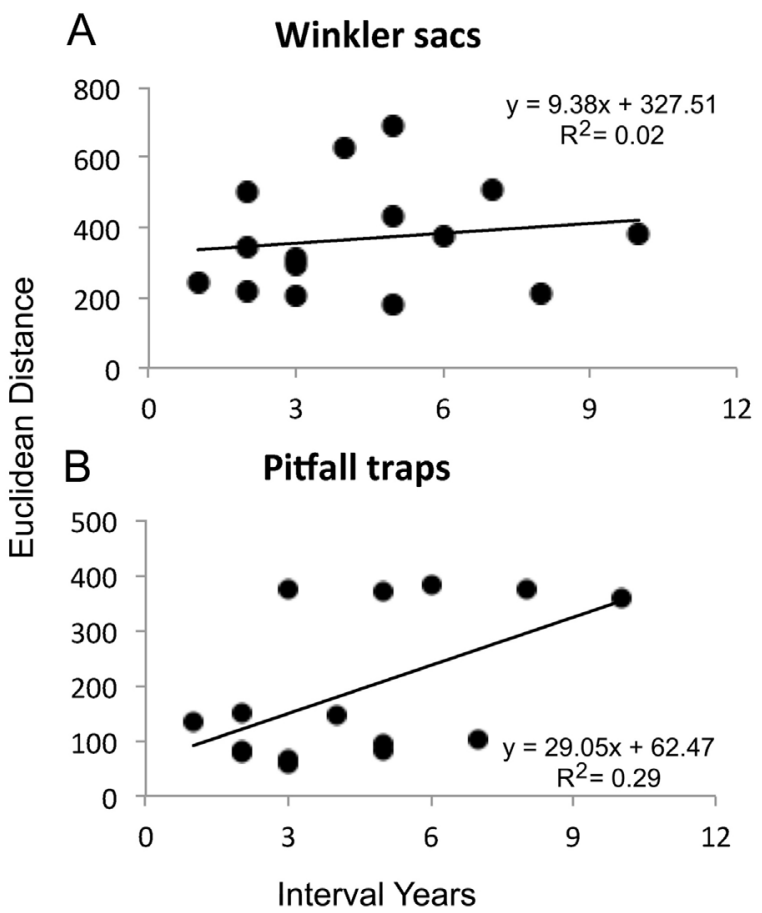

Fig. 4. Euclidean distances separating ant communities at increasing census intervals.

poral stability in species richess and community structure across the whole study period (2003-2011) presented by the Otongachi ant fauna is inconsistent with general expectations of effects of global stressors on local communities. For example, both habitat degradation and global warming are predicted to accelerate the loss of biodiversity (Gibb et al., 2015; Baez et al., 2016). Global warming $(\mathrm{GW})$ is perhaps the major challenge facing natural communities nowadays and Andean forests like Otongachi have already experienced major increases in average yearly temperature (Mora et al., 2013). Generally, it is expected that due to global warming species distributions will shift, moving polewards in latitude and upwards in elevation, when possible (Parmesan and Yohe, 2003). For example, the Edith's checkerspot butterfly (Euphydryas editha), which lives in the US and Canada's East coast, may have moved up to two degrees northward in over a decade (Parmesan, 1996). Furthermore, species abundances of thermophilic taxa in Europe are known to increase under current global warming (Bowler et al., 2017). However, these scenarios of drastic shifts in species ranges in temperate regions contrast with the lack of predictions of species responses in tropical areas (Lenoir and Svenning, 2013). In fact, little theory is available forecasting the future of communities liv- ing at the Equator ( $0^{\circ}$ in latitude) and at sea level ( $0 \mathrm{~m}$ a.s.l.). In tropical forests, species adapted to narrow ranges in temperature (Janzen, 1967) may find it difficult to move polewards or upwards. Some studies have proposed that narrow temperature changes with latitude will make most distribution shifts to be upwards, not polewards (Bush, 2002). Yet extrapolation of these ideas to all taxa is difficult because not all taxa have shown the same response to altitude (Schuldt et al., 2015). This scenario led Colwell et al. (2008) to suggest that most tropical communities may be 'between the devil and the deep blue sea' and under danger of biological attrition. However, few documented examples currently exist in Andean ecosystems where little research has been done and it is strongly biased to certain taxa (i.e. plants and frogs) and observational (not experimental) studies (Baez et al., 2016). The study here presented found that the Otongachi ant community neither lost nor gained species in the last 11 years. The high temporal stability of the Otongachi ant community is thus in line with these studies, suggesting that dispersal capabilities of tropical ant species are limited and that distribution ranges in the tropics are narrow (Deutsch et al., 2008).

This study shows that tropical leaf-litter ant communities are highly dynamic in time, on average, only half of the ant species caught in one census were recovered in the following census. This pattern is supported by many natural history observations. For example, during the course of this study at least two species, Stenamma alas and Lenomyrmex wardi (two leaf litter ant species not recorded with our traps) were common in the reserve (Ramón et al., 2013), but attempts to find them in my survey were unsuccessful. Furthermore, as opposed to ants in Winkler traps, the ants in pitfall traps presented weak indication of directional change. Hence, the Otongachi leaf litter ant community can be divided in two compartments. The Winkler compartment contains the more diverse and cryptic fauna. The pitfall compartment contains less diversity, but is formed by larger and more mobile ants (Donoso and Ramoín, 2009). With the data at hand is it unclear why the trajectories of pitfall ants show directional change, the patterns of species appearances/disappearances, and that of MRA, are all too weak to articulate mechanisms behind these patters. But I hypothesize that the stronger response of the pitfall fauna may depend on the higher dispersal abilities of larger and long-legged ants (Kaspari and Weiser, 2007). Importantly, these same characteristics (larger ants, with higher dispersal abilities) and their propensity to show directional change make the pitfall compartment the best subset of the ant community to indicate ecological perturbance. Thus, conclusions made by short-term studies should be revisited, as species appearing/disapearing from a site may be rather the rule, difficult to separate from responses to different sources of ecological stress. More studies are needed that quantify how strong fluctuations at the species-level impact the patterns gathered from complete ant communities.

Only six species, out of 126 leaf-litter species currently known in Otongachi, were constantly among the most abundant species. Instead, up to ten other species reached high abundance in one year, but failed to keep the pace in others. Magurran and Henderson (2003) found a similar pattern, splitting core and occasional species in a fish community. Studying a stuarine fish community for 21 years, they noticed that core fish species differ in their habitat preferences from occasional species. One explanation for such split suggest that core species are well adapted to the local environment, while occasional should not and their presence in the community is likely limited by dispersal (Tsang and Bonebrake, 2016).

There is an important caveat to this study. The pattern recovered for the Otongachi ant community may be partially explained by sampling artifacts, where the amount of traps used in a year $(n=20$, per trap) was insufficient to thoroughly sample the whole ant community. This may not be the case in this study because the protocol 
I used here (ALL Protocol, Agosti et al., 2000) has been shown elsewhere to be robust. However, long-term datasets may still contain outlier years, where either inadequate sampling or responses to singular weather events will bias community structure. One such case may be present in my dataset. For instance, the decrease in species richness in 2011 (Fig. 1) may have impacted the rate of species appearing and disappearing in that year (Fig. 2). Whereas stronger analyses, needed to identify these outlier communities and quantify their impacts on temporal patterns, are beyond the scope of this work, it is clear that long-term monitoring may help to correct for intrinsic biases of years inadequately sampled.

In conclusion, eleven years after the first census was made in the year 2003, the Otongachi ant community presents no indication of it undergoing significant structural change. This is significant because mountain forests near the equator are already facing signifand because the diversity of different animal and plant groups is already declining worldwide (Butchart et al., 2010). Clearly, more effort should be put in documenting responses of insect populations to GW, especially those in global biodiversity hotspots like Andean cloud forests (Baez et al., 2016). Furthermore, the analysis presented here suggests a minor effect of temporal fluctuations of individual species on overall community composition, with direct implications to monitoring schemes that generally focus on one icant global warming (Nogués-Bravo et al., 2007; Mora et al., 2013),

or a few species within the community. Finally, continuous monitoring of the Otongachi ant community as well as information on species physiological limits, and their altitudinal and latitudinal ranges (and how these ranges are changing with time) may be esential to forecast the response of this tropical ant community to local and global perturbations.

\section{Acknowledgements}

This work could not have been possible without the help of all the people that have surveyed the Otongachi ant community since 2003. S. Tello, J. Vieira, A. Kumar, D. Proaño, A. Pinos, N. Andrade, P. Terán, A. Barragán, G. Ramón, V. Diaz, V. Crespo, T. Delsinne, L.-L. Finn, M. Bustamante and D. Dominguez, all shared the painful fieldwork needed to gather the datasets. Special thanks to G. Ramón for overseeing lab and fieldwork during several years. J.D. SantillanaOrtiz and K. Roeder for comments and revisions to the manuscript. G. Onore and I. Tapia for long-term support to this research and for their impetus and energy in preserving the Otongachi forest.

\section{Appendix A.}

Table A1

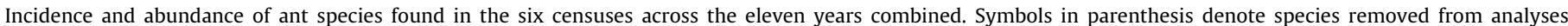
( $\mathrm{S}=$ Singletons, $\mathrm{N}=$ Nomadic, ${ }^{*}=$ Other $)$.

\begin{tabular}{|c|c|c|c|c|c|c|c|}
\hline \multirow[t]{2}{*}{ SPECIES } & & \multicolumn{3}{|c|}{ INCIDENCE } & \multicolumn{3}{|c|}{ ABUNDANCE } \\
\hline & & Pitfall & Winkler & Total & Pitfall & Winkler & Total \\
\hline Acanthognathus teledectus & & & 5 & 5 & & 38 & 38 \\
\hline Acanthoponera minor & & 1 & 1 & 2 & 2 & 2 & 4 \\
\hline Acromyrmex EC001 & $(\mathrm{S})$ & & 1 & 1 & & 3 & 3 \\
\hline Acropyga EC001 & & & 3 & 3 & & 10 & 10 \\
\hline Adelomyrmex EC001 & & & 3 & 3 & & 3 & 3 \\
\hline Anochetus EC001 & & 2 & 1 & 3 & 3 & 21 & 24 \\
\hline Anochetus EC002 & & 1 & 3 & 4 & 7 & 11 & 18 \\
\hline Apterostigma EC001 & & & 3 & 3 & & 58 & 58 \\
\hline Apterostigma EC002 & & 5 & 5 & 10 & 10 & 45 & 55 \\
\hline Apterostigma EC003 & & 3 & 5 & 8 & 17 & 26 & 43 \\
\hline Apterostigma EC004 & & 1 & 1 & 2 & 1 & 3 & 4 \\
\hline Apterostigma EC005 & & 1 & 4 & 5 & 1 & 54 & 55 \\
\hline Atta EC001 & $\left(^{*}\right)$ & 3 & & 3 & 4 & & 4 \\
\hline Azteca EC001 & & 4 & 4 & 8 & 378 & 13 & 391 \\
\hline Azteca EC002 & & & 2 & 2 & & 2 & 2 \\
\hline Brachymyrmex EC001 & & 3 & 6 & 9 & 6 & 142 & 148 \\
\hline Brachymyrmex EC002 & & 1 & 1 & 2 & 7 & 3 & 10 \\
\hline Carebara urichi & & 3 & 4 & 7 & 19 & 61 & 80 \\
\hline Cerapachys nr_augustae & $(\mathrm{N})$ & & 1 & 1 & & 1 & 1 \\
\hline Cerapachys nr toltecus & $(\mathrm{N})$ & & 2 & 2 & & 10 & 10 \\
\hline Cerapachys splendens & $(\mathrm{N})$ & & 2 & 2 & & 3 & 3 \\
\hline Crematogaster EC001 & & 1 & 5 & 6 & 1 & 85 & 86 \\
\hline Crematogaster EC003 & $(\mathrm{S})$ & & 1 & 1 & & 1 & 1 \\
\hline Crematogaster EC004 & & 1 & 2 & 3 & 1 & 12 & 13 \\
\hline Cyphomyrmex EC001 & & 3 & 2 & 5 & 4 & 3 & 7 \\
\hline Cyphomyrmex EC003 & & 6 & 6 & 12 & 23 & 508 & 531 \\
\hline Cyphomyrmex EC004 & & 2 & 2 & 4 & 2 & 4 & 6 \\
\hline Discothyrea EC001 & & & 2 & 2 & & 4 & 4 \\
\hline Dorymyrmex EC001 & $(S)$ & 1 & & 1 & 1 & & 1 \\
\hline Ectatomma ruidum & & 2 & & 2 & 7 & & 7 \\
\hline Gnamptogenys annulata & $\left(^{*}\right)$ & 2 & & 2 & 2 & & 2 \\
\hline Gnamptogenys bisulca & & 6 & 6 & 12 & 92 & 315 & 407 \\
\hline Gnamptogenys continua & & & 4 & 4 & & 43 & 43 \\
\hline Gnamptogenys EC002 & $(\mathrm{S})$ & 1 & & 1 & 1 & & 1 \\
\hline Gnamptogenys fernandezi & $(\mathrm{S})$ & & 1 & 1 & & 1 & 1 \\
\hline Gnamptogenys minuta & & 1 & 1 & 2 & 1 & 1 & 2 \\
\hline Gnamptogenys perpicax & $\left({ }^{*}\right)$ & 2 & & 2 & 2 & & 2 \\
\hline Hylomyrma EC001 & & 6 & 6 & 12 & 14 & 207 & 221 \\
\hline Hypoponera distinguenda & & 5 & 6 & 11 & 26 & 386 & 412 \\
\hline Hypoponera EC001 & & & 2 & 2 & & 7 & 7 \\
\hline Hypoponera EC002 & & 1 & 4 & 5 & 2 & 33 & 35 \\
\hline Hypoponera EC003 & $(\mathrm{S})$ & & 1 & 1 & & 1 & 1 \\
\hline
\end{tabular}


Table A1 (Continued)

\begin{tabular}{|c|c|c|c|c|c|c|c|}
\hline \multirow[t]{2}{*}{ SPECIES } & & \multicolumn{3}{|c|}{ INCIDENCE } & \multicolumn{3}{|c|}{ ABUNDANCE } \\
\hline & & Pitfall & Winkler & Total & Pitfall & Winkler & Total \\
\hline Hypoponera EC004 & & 1 & 3 & 4 & 2 & 22 & 24 \\
\hline Hypoponera EC005 & & & 2 & 2 & & 4 & 4 \\
\hline Hypoponera EC006 & & & 3 & 3 & & 6 & 6 \\
\hline Hypoponera EC007 & & 2 & 6 & 8 & 6 & 133 & 139 \\
\hline Labidus coecus & $(\mathrm{N})$ & 1 & & 1 & 1 & & 1 \\
\hline Labidus praedator & $(\mathrm{N})$ & 2 & & 2 & 412 & & 412 \\
\hline Labidus spininodis & $(\mathrm{N})$ & 2 & 1 & 3 & 746 & 201 & 947 \\
\hline Lenomyrmex foveolatus & & 1 & 3 & 4 & 1 & 4 & 5 \\
\hline Leptogenys EC001 & & 1 & 2 & 3 & 1 & 2 & 3 \\
\hline Leptogenys famelica & $(\mathrm{S})$ & 1 & & 1 & 1 & & 1 \\
\hline Megalomyrmex bidentatus & & 2 & & 2 & 3 & & 3 \\
\hline Megalomyrmex EC002 & & 6 & 2 & 8 & 51 & 14 & 65 \\
\hline Megalomyrmex incisus & & & 2 & 2 & & 27 & 27 \\
\hline Megalomyrmex mondabora & & & 2 & 2 & & 15 & 15 \\
\hline Megalomyrmex silvestrii & & & 4 & 4 & & 6 & 6 \\
\hline Myrmelachista EC001 & & 2 & & 2 & 2 & & 2 \\
\hline Myrmelachista EC002 & $(*)$ & 3 & & 3 & 3 & & 3 \\
\hline Myrmicocrypta EC001 & & 2 & 3 & 5 & 3 & 9 & 12 \\
\hline Neivamyrmex EC001 & $(\mathrm{N})$ & 1 & 1 & 2 & 80 & 2 & 82 \\
\hline Neivamyrmex EC002 & $(\mathrm{N})$ & 2 & & 2 & 2 & & 2 \\
\hline Neoponera chyzeri & & 4 & 1 & 5 & 37 & 11 & 48 \\
\hline Neoponera unidentata & & 1 & 3 & 4 & 3 & 5 & 8 \\
\hline Neoponera verenae & & 3 & & 3 & 22 & & 22 \\
\hline Nylanderia EC001 & & & 2 & 2 & & 10 & 10 \\
\hline Nylanderia EC002 & & 1 & 4 & 5 & 1 & 166 & 167 \\
\hline Nylanderia ECOO4 & & 2 & 5 & 7 & 12 & 638 & 650 \\
\hline Ochetomyrmex EC001 & $(\mathrm{S})$ & & 1 & 1 & & 2 & 2 \\
\hline Octostruma EC001 & & 1 & 6 & 7 & 7 & 403 & 410 \\
\hline Octostruma EC002 & & 2 & 5 & 7 & 4 & 245 & 249 \\
\hline Odontomachus bauri & & 5 & 3 & 8 & 18 & 24 & 42 \\
\hline Odontomachus EC001 & & 1 & 3 & 4 & 2 & 9 & 11 \\
\hline Pachycondyla harpax & & 6 & 6 & 12 & 75 & 26 & 101 \\
\hline Pachycondyla impressa & & 6 & 4 & 10 & 49 & 7 & 56 \\
\hline Pheidole EC001 & & 4 & 3 & 7 & 84 & 74 & 158 \\
\hline Pheidole EC002 & & 6 & 6 & 12 & 80 & 77 & 157 \\
\hline Pheidole EC003 & & 5 & 5 & 10 & 41 & 152 & 193 \\
\hline Pheidole EC004 & & 5 & 3 & 8 & 28 & 5 & 33 \\
\hline Pheidole EC005 & & 3 & 6 & 9 & 25 & 134 & 159 \\
\hline Pheidole EC006 & & 6 & 4 & 10 & 60 & 8 & 68 \\
\hline Pheidole EC007 & & 1 & 2 & 3 & 64 & 5 & 69 \\
\hline Pheidole EC008 & & 2 & & 2 & 6 & & 6 \\
\hline Pheidole EC009 & & 6 & 5 & 11 & 445 & 177 & 622 \\
\hline Pheidole EC010 & & 1 & 6 & 7 & 2 & 144 & 146 \\
\hline Pheidole EC012 & & 5 & 3 & 8 & 23 & 17 & 40 \\
\hline Pheidole EC013 & & 1 & 1 & 2 & 2 & 1 & 3 \\
\hline Pheidole EC015 & $(\mathrm{S})$ & 1 & & 1 & 1 & & 1 \\
\hline Pheidole EC016 & & 2 & 5 & 7 & 3 & 138 & 141 \\
\hline Pheidole EC017 & & 5 & 4 & 9 & 10 & 26 & 36 \\
\hline Pheidole EC018 & & 3 & & 3 & 3 & & 3 \\
\hline Pheidole EC020 & $(\mathrm{S})$ & & 1 & 1 & & 2 & 2 \\
\hline Pheidole EC021 & & & 2 & 2 & & 8 & 8 \\
\hline Pheidole onyx & & & 3 & 3 & & 62 & 62 \\
\hline Pheidole sp26 & $\left({ }^{*}\right)$ & 2 & & 2 & 7 & & 7 \\
\hline Pheidole sp27 & $(\mathrm{S})$ & & 1 & 1 & & 3 & 3 \\
\hline Prionopelta amabilis & $(*)$ & & 2 & 2 & & 40 & 40 \\
\hline Prionopelta modesta & $(*)$ & & 3 & 3 & & 18 & 18 \\
\hline Probolomyrmex EC001 & $(\mathrm{N})$ & & 1 & 1 & & 1 & 1 \\
\hline Proceratium convexiceps & $(\mathrm{S})$ & & 1 & 1 & & 1 & 1 \\
\hline Procryptocerus EC001 & $(\mathrm{S})$ & 1 & & 1 & 2 & & 2 \\
\hline Protalaridris armata & & & 5 & 5 & & 29 & 29 \\
\hline Pseudoponera gilberti & & & 3 & 3 & & 13 & 13 \\
\hline Rasopone becculata & & 1 & 3 & 4 & 1 & 3 & 4 \\
\hline Rhopalothrix EC002 & & & 2 & 2 & & 8 & 8 \\
\hline Rogeria blanda & & & 6 & 6 & & 51 & 51 \\
\hline Rogeria EC002 & & & 3 & 3 & & 12 & 12 \\
\hline Solenopsis spp & & 6 & 6 & 12 & 157 & 3332 & 3489 \\
\hline Stigmatomma lurilabes & $(\mathrm{S})$ & & 1 & 1 & & 2 & 2 \\
\hline Strumigenys EC001 & & & 6 & 6 & & 206 & 206 \\
\hline Strumigenys EC002 & & & 3 & 3 & & 6 & 6 \\
\hline Strumigenys EC003 & & & 4 & 4 & & 23 & 23 \\
\hline Strumigenys EC004 & & 1 & 5 & 6 & 1 & 22 & 23 \\
\hline Strumigenys EC005 & $(\mathrm{S})$ & & 1 & 1 & & 11 & 11 \\
\hline Strumigenys EC007 & $(S)$ & & 1 & 1 & & 1 & 1 \\
\hline Strumigenys EC009 & (S) & & 1 & 1 & & 9 & 9 \\
\hline
\end{tabular}


Table A1 (Continued)

\begin{tabular}{|c|c|c|c|c|c|c|c|}
\hline \multirow[t]{2}{*}{ SPECIES } & & \multicolumn{3}{|c|}{ INCIDENCE } & \multicolumn{3}{|c|}{ ABUNDANCE } \\
\hline & & Pitfall & Winkler & Total & Pitfall & Winkler & Total \\
\hline Strumigenys EC010 & & & 3 & 3 & & 12 & 12 \\
\hline Strumigenys EC013 & & & 2 & 2 & & 15 & 15 \\
\hline Strumigenys EC014 & & & 2 & 2 & & 3 & 3 \\
\hline Tapinoma EC001 & $(\mathrm{S})$ & & 1 & 1 & & 1 & 1 \\
\hline Tatuidris tatusia & & 1 & 3 & 4 & 7 & 8 & 15 \\
\hline Thaumatomyrmex zeteki & & & 2 & 2 & & 2 & 2 \\
\hline Trachymyrmex EC001 & $(\mathrm{S})$ & 1 & & 1 & 1 & & 1 \\
\hline Trachymyrmex EC002 & (S) & 1 & & 1 & 1 & & 1 \\
\hline Typhlomyrmex pusillus & & & 3 & 3 & & 18 & 18 \\
\hline Wasmannia auropunctata & & 4 & 7 & 11 & 16 & 103 & 119 \\
\hline TOTAL & & 571 & 1251 & 1822 & 3248 & 9094 & 12342 \\
\hline
\end{tabular}

\section{References}

Agosti, D., Majer, J.D., Alonso, L.E., Schultz, T.R., 2000. Ants: Standard Methods for Measuring and Monitoring Biodiversity. Smithsonian Institution Press, Washington D.C., USA.

Andersen, A.N., 1990. The use of ant communities to evaluate change in Australian terrestrial ecosystems: a review and a recipe. Proc. Ecol. Soc. Aust. 16, 347-357.

Andersen, A.N., 1991. Responses of ground-foraging ant communities to three experimental fire regimes in a savanna forest of tropical Australia. Biotropica 23, 575-585, http://dx.doi.org/10.2307/2388395.

Anderson-Teixeira, K.J., et al., 2015. CTFS-ForestGEO: a worldwide network monitoring forests in an era of global change. Glob. Change Biol. 21, 528-549, http://dx.doi.org/10.1111/gcb.12712.

Arcila, A.M., Lozano-Zambrano, F.H., 2003. Hormigas como herramientas para la bioindicación y el monitoreo. In: Fernández, F. (Ed.), Introducción a las hormigas de la región Neotropical. Instituto de Investigación de Recursos Biológicos Alexander von Humboldt, Colombia, pp. 159-166.

Baez, S., Jaramillo, L., Cuesta, F., Donoso, D.A., 2016. Effects of climate change on the biodiversity of the Andean Region: a synthesis of published studies until 2015. Neotropical Biodivers. 2, 181-194, http://dx.doi.org/10.1080/23766808.2016. 1248710.

Belcher, A.K., Berenbaum, M.R., Suarez, A.V., 2016. Urbana house ants 2.0: revisiting M. R. Smith's 1926 survey of house-infesting ants in central Illinois after 87 years. Am. Entomol. 62, 182-193, http://dx.doi.org/10.1093/ae/tmw041.

Bihn, J.H., Gebauer, G., Brandl, G., 2010. Loss of functional diversity of ant assemblages in secondary tropical forests. Ecology 91, 782-792.

Bonada, N., Prat, N., Resh, V.H., Statzner, B., 2006. Developments in aquatic insect biomonitoring: a comparative analysis of recent approaches. Annu. Rev. Entomol. 51, 495-523.

Bowler, D.E., Hof, C., Haase, P., Kröncke, I., Schweiger, O., Adrian, R., Baert, L., Bauer, H.-G., Blick, T., Brooker, R.W., Dekoninck, W., Domisch, S., Eckmann, R., Hendrickx, F., Hickler, T., Klotz, S., Kraberg, A., Kühn, I., Matesanz, S., Meschede, A., Neumann, H., O'Hara, R., Russell, D.J., Sell, A.F., Sonnewald, M., Stoll, S., Sundermann, A., Tackenberg, O., Türkay, M., Valladares, F., van Herk, K., van Klink, R., Vermeulen, R., Voigtländer, K., Wagner, R., Welk, E., Wiemers, M., Wiltshire, K.H., Böhning-Gaese, K., 2017. Cross-realm assessment of climate change impacts on species' abundance trends. Nat. Ecol. Evol. 1, A:0067.

Bush, M.B., 2002. Distributional change and conservation on the Andean flank: a palaeoecological perspective. Glob. Ecol. Biogeogr. 11, 463-473, http://dx.doi. org/10.1046/j.1466-822X.2002.00305.x.

Butchart, S.H.M., Walpole, M., Collen, B., van Strien, A., Scharlemann, J.P.W., Almond, R.E.A., Baillie, J.E.M., Bomhard, B., Brown, C., Bruno, J., Carpenter, K.E. Carr, G.M., Chanson, J., Chenery, A.M., Csirke, J., Davidson, N.C., Dentener, F., Foster, M., Galli, A., Galloway, J.N., Genovesi, P., Gregory, R.D., Hockings, M., Kapos, V., Lamarque, J.-F., Leverington, F., Loh, J., McGeoch, M.A., McRae, L., Minasyan, A., Hernández Morcillo, M., Oldfield, T.E.E., Pauly, D., Quader, S., Revenga, C., Sauer, J.R., Skolnik, B., Spear, D., Stanwell-Smith, D., Stuart, S.N., Symes, A., Tierney, M., Tyrrell, T.D., Vié, J.-C., Watson, R., 2010. Global biodiversity: indicators of recent declines. Science 328, 1164-1167, http://dx. doi.org/10.1126/science.1187512.

Callahan, J.T., 1984. Long-term ecological research. Bioscience 34, 363-367.

Cañadas, L., 1983. El Mapa Bioclimaítico y Ecoloígico del Ecuador. Banco Central del Ecuador, Quito, Ecuador.

Collins, S.L., Micheli, F., Hartt, L., 2000. A method to determine rates and patterns of variability in ecological communities. Oikos 91, 285-293.

Collins, S.L., Suding, K.N., Cleland, E.E., Batty, M., Pennings, S.C., Gross, K.L., Grace, J., Gough, L., Fargione, J.E., Clark, C., 2008. Rank clocks and plant community dynamics. Ecology 89, 3534-3541.

Collins, S.L., 2000. Disturbance frequency and community stability in native tallgrass prairie. Am. Nat. 155, 311-325.

Colwell, R.K., Brehm, G., Cardelús, C.L., Gilman, A.C., Longino, J.T., 2008. Global warming, elevational range shifts, and lowland biotic attrition in the wet tropics. Science 322, 258-261.

da Conceição, E.S., Delabie, J.H.C., Della Lucia, T.M.C., Costa-Neto, A. de O., Majer, J.D., 2015. Structural changes in arboreal ant assemblages (Hymenoptera:
Formicidae) in an age sequence of cocoa plantations in the south-east of Bahia, Brazil. Austral Entomol. 54, 315-324, http://dx.doi.org/10.1111/aen.12128.

Del Toro, I., Ribbons, R.R., Pelini, S.L., 2012. The little things that run the world revisited: a review of ant-mediated ecosystem services. Myrmecol. News 17, 133-146.

Deutsch, C.A., Tewksbury, J.J., Huey, R.B., Sheldon, K.S., Ghalambor, C.K., Haak, D.C., Martin, P.R., 2008. Impacts of climate warming on terrestrial ectotherms across latitude. Proc. Natl. Acad. Sci. U. S. A. 105, 6668-6672.

Donoso, D.A., Ramoín, G., 2009. Composition of a high diversity leaf litter ant community (Hymenoptera: Formicidae) from an Ecuadorian pre-montane rainforest. Ann. Soc. Entomol. Fr. 45, 487-499.

Donoso, D.A., Johnston, M.K., Clay, N.A., Kaspari, M., 2013. Trees as templates for trophic structure of tropical litter arthropod fauna. Soil Biol. Biogeochem. 61, 45-51, http://dx.doi.org/10.1016/j.soilbio.2013.02.004.

Gibb, H., Sanders, N.J., Dunn, R.R., Watson, S., Photakis, M., Abril, S., Andersen, A.N., Angulo, E., Armbrecht, I., Arnan, X., Baccaro, F.B., Bishop, T.R., Boulay, R., Castracani, C., del Toro, I., Delsinne, T., Diaz, M., Donoso, D.A., Enríquez, M.L., Fayle, T.M., Feener, D.H.Jr., Fitzpatrick, M.C., Gómez, C., Grasso, D.A., Groc, S., Heterick, B., Hoffmann, B.D., Lach, L., Lattke, J., Leponce, M., Lessard, J.-P., Longino, J., Lucky, A., Majer, J., Menke, S.B., Mezger, D., Mori, A., Munyai, T.C. Paknia, O., Pearce-Duvet, J., Pfeiffer, M., Philpott, S.M., de Souza, J.L.P., Tista, M., Vasconcelos, H.L., Vonshak, M., Parr, C.L., 2015. Climate regulates the effects of disturbance on ant assemblage structure. Proc. R. Soc. Lond. B Biol. 282, 20150418, http://dx.doi.org/10.1098/rspb.2015.0418.

Gosper, C.R., Yates, C.J., Prober, S.M., 2012. Changes in plant species and functional composition with time since fire in two Mediterranean-climate plant communities. J. Veg. Sci. 23, 1071-1081

Hallett, L.M., Jones, S.K., MacDonald, A.M., Flynn, D.F.B., Slaughter, P., Ripplinger, J., Collins, S.L., Gries, C., Jones, M.B., 2015. codyn: Community dynamics metrics. R package version 1.0.1. https://github.com/laurenmh/codyn/.

Hallett, L.M., Jones, S.K., Macdonald, A.A.A., Jones, M.B., Flynn, D.F.B., Ripplinger, J., Slaughter, P., Gries, C., Collins, S.L., 2016. CODYN: An R package of community dynamics metrics. Methods Ecol. Evol. 7, 1146-1151, http://dx.doi.org/10. 1111/2041-210X.12569.

Hoffman, B.D., Andersen, A.N., 2003. Responses of ants to disturbance in Australia, with particular reference to functional groups. Austral Ecol. 28, 444-464

Jackson, G.P., Fox, B.J., 1996. Comparison of regeneration following burning, clearing or mineral sand mining at Tomago, NSW. II. Succession of ant assemblages in a coastal forest. Aust. J. Ecol. 21, 200-216.

Janzen, D.H., 1967. Why mountain passes are higher in the tropics. Am. Nat. 101, 233-249.

Jaramillo, J., 2001. The Flora of the Rio Guajalito, Mountain Rain Forest (Ecuador). In: Nieder J., Barthlott W. (eds.), Results of the Bonn-Quito epiphyte Project. Funded by the Volkswagen Foundation (Vol. 1 of 2). Bonn, Germany.

Kampe, T.U., Johnson, B.R., Kuester, M., Keller, M., 2010. NEON: the first continental-scale ecological observatory with airborne remote sensing of vegetation canopy biochemistry and structure. J. Appl. Remote Sens. 4, 043510.

Kaspari, M., Weiser, M., 2007. The size-grain hypothesis: do macroarthropods see a fractal world? Ecol. Entomol 32, 279-282.

Lafleur, B., Parsons, W.F.J., Bradley, R.L., Francoeur, A., 2006. Ground-nesting ant assemblages and their relationships to habitat factors along a chronosequence of postfire-regenerated lichen-spruce woodland. Environ. Entomol. 35, $1515-1524$.

Lenoir, J., Svenning, J.-C., 2013. Latitudinal and elevational range shifts under contemporary climate change. In: Levin, S.A. (Ed.), Encyclopedia of Biodiversity. , pp. 599-611.

Magurran, A.E., Henderson, P.A., 2003. Explaining the excess of rare species in natural species abundance distributions. Nature 422, 714-716, http://dx.doi $\operatorname{org} / 10.1038 /$ nature01547.

Magurran, A.E., Baillie, S.R., Buckland, S.T., Dick J.McP. Elston, D.A., Scott, M., Smith, R.I., Somerfield, P.J., Watt, A.D., 2010. Long-term data- sets in biodiversity research and monitoring: assessing change in ecological communities through time. Trends Ecol. Evol. 25, 574-582.

Majer, J.D., Nichols, O.G., 1998. Long-term recolonization patterns of ants in Western Australian rehabilitated bauxite mines, with reference to use as indicators of restoration success. J. Appl. Ecol. 35, 161-181, http://dx.doi.org/ 10.1046/j.1365-2664.1998.00286.x. 
Majer, J.D., Sartiori, M., Stone, R., Perriman, W.S., 1982. Recolonization by ants and other invertebrates in rehabilitated mineral sand mines near Eneabba, Western Australia. Reclam. Reveg. Res. 1, 63-81.

Majer, J.D., Day, J.E., Kabay, E.D., Perriman, W.S., 1984. Recolonisation by ants in bauxite mines rehabilitated by a number of different methods. J. Appl. Ecol. 21, 355-375, http://dx.doi.org/10.2307/2403059.

Majer, J.D., Orabi, G., Bisevac, L., 2007. Ants (Hymenoptera: Formicidae) pass the bioindicator scorecard. Myrmecol. News 10, 69-76.

Majer, J.D., Heterick, B., Gohr, T., Hughes, E., Mounsher, L., Grigg, A., 2013. Is thirty-seven years sufficient for full return of the ant biota following restoration? Ecol. Process. 2, http://dx.doi.org/10.1186/2192-1709-2-19, 2192-1709.

Majer, J.D., 1981. W.A. Forests Department bulletin, no. 93. In: The Role of Invertebrates in Bauxite Mine Rehabilitation. WA Forests Department, Perth.

Majer, J.D., 1983. Ants: bio-indicators of minesite rehabilitation, land-use, and land conservation. Environ. Manage. 7, 375-383.

Matthews, W.J., Marsh-Matthews, E., Cashner, R.C., Gelwick, F., 2013. Disturbance and trajectory of change in a stream fish community over four decades. Oecologia 173, 955-969, http://dx.doi.org/10.1007/s00442-013-2646-3.

Mora, C., Frazier, A.G., Longman, R.J., Dacks, R.S., Walton, M.M., Tong, E.J., Sanchez, J.J., Kaiser, L.R., Stender, Y.O., Anderson, J.M., Ambrosino, C.M., Fernandez-Silva, I., Giuseffi, L.M., Giambelluca, T.W., 2013. The projected timing of climate departure from recent variability. Nature 502, 183-187, http://dx.doi.org/10. 1038/nature12540.

Nogués-Bravo, D., Araújo, M.B., Errea, M.P., Martinez-Rica, J.P. 2007. Exposure of global mountain systems to climate warming during the 21 st century. Glob. Environ. Change 17, 420-428.
Parmesan, C., Yohe, G., 2003. A globally coherent fingerprint of climate change impacts across natural systems. Nature 421 (6918), 37-42.

Parmesan, C., 1996. Climate and species' range. Nature 382, 765-766.

Patrick, M., Fowler, D., Dunn, R.R., Sanders, N.J., 2012. Effects of treefall gap disturbances on ant assemblages in a tropical montane cloud forest. Biotropica 44, 472-478, http://dx.doi.org/10.1111/j.1744-7429.2012.00855.x.

Ramón, G., Barragán, A., Donoso, D.A., 2013. Can clay banks increase the local ant species richness of a montane forest? Métodos en Ecología y Sistemática 8 , 37-53.

Schuldt, A., Wubet, T., Buscot, F., Staab, M., Assmann, T., Böhnke-Kammerlander, M., Both, S., Erfmeier, A., Klein, A.M., Ma, K., Pietsch, K., Schultze, S., Wirth, C. Zhang, J., Zumstein, P., Bruelheide, H., 2015. Multitrophic diversity in a biodiverse forest is highly nonlinear across spatial scales. Nat. Commun. 6, 10169.

Tiede, I., Schlautmann, J., Donoso, D.A., Wallis, C.I.B., Bendix, J., Brandl, R., Farwig, N., 2017. Ants as indicators of environmental change and ecosystem processes. Ecol. Indic. 83, 527-537, http://dx.doi.org/10.1016/j.ecolind.2017.01.029.

Tsang, T.P.N., Bonebrake, T.C. 2016. Contrasting roles of environmental and spatial processes for common and rare urban butterfly species compositions. Landsc. Ecol. 32, 47, http://dx.doi.org/10.1007/s10980-016-0427-1.

Vanderwoude, C., Lobry de Bruyn, L.A., House, A.P.N., 2000. Long-term ant community responses to selective harvesting of timber from Spotted Gum (Corymbia variegata)-dominated forests in south-east Queensland. Ecol. Manage Restor. 1, 204-214. 